\title{
PERANAN PEMELIHARAAN TANAMAN MANGGIS TERHADAP PENDAPATAN PETANI DI JAWA BARAT
}

\author{
${ }^{1}$ Eti Suminartika \\ ${ }^{1}$ Departemen Agribisnis Fakultas pertanian Universitas Padjadjaran \\ Email: eti_st@yahoo.com
}

\begin{abstract}
ABSTRAK
Pangsa pasar manggis masih terbuka lebar baik di dalam maupun di luar negeri, namun hanya 10 persen manggis kita yang dapat diekspor, hal tersebut disebabkan oleh budidaya tanaman manggis masih sangat tradisional, jarang dipupuk, dibersihan dan dipangkas. Tujuan penelitian ini adalah menganalisis pemeliharaan tanaman manggis, menganalisis perbedaan pendapatan usahatani manggis dan menganalisis kontribusi pendapatan usahatani manggis terhadap pendapatan keluarga petani. Penelitian ini menggunakan data sekunder dan primer dengan menggunakan metoda survey. Selanjutnya data dianalisis dengan menggunakan analisis deskriptif, matematik dan ekonometrik. Penelitian dilaksanakan di sentra produksi manggis Jawa Barat yaitu di kabupaten Tasikmalaya dan Subang. Hasil penelitian menunjukkan petani manggis di kabupaten Tasikmalaya lebih lebih memelihara tanaman manggisnya dibandingkan di kabupaten Subang, meskipun demikian pemeliharaan tanaman di kedua kabupaten tersebut masih dibawah standar, dampaknya, pendapatan dan keuntungan usahatani manggis di kabupaten Tasikmalaya lebih tinggi dibanding di kabupaten Subang dengan perbedaan yang signifikan secara statistik, oleh karenanya, pendapatan usahatani manggis memiliki peranan yang besar terhadap pendapatan keluarga petani di kabupaten Tasikmalaya.
\end{abstract}

Kata kunci: manggis, pendapatan, keuntungan, pemeliharaan tanaman.

\section{ABSTRACT}

Market share of mangosteen is still high both in the local and foreign market, but only 10 per cent of Indonesian mangosteen can be exported. This is due to improper cultivation method such as rarely fertilizing, weeding and other maintenance. Lack of maintenance of mangosteen farm can lowers the quality and productivity of trees. The purpose of this study was to analyse the maintenance of mangosteen farm, the differences of mangosteen farm income and the contribution of mangosteen farm income to the family income. This study used secondary and primary data which obtained from farmers, by using survey method. The data were analysed by using descriptive, mathematics and econometrics analysis. Research was conducted in two of mangosteen production centres in West Java, namely Tasikmalaya and Subang district. The results show that mangosteen farmers in the Tasikmalaya is better at maintaining their garden than those in Subang, though the maintenance of the two districts are still below standard. The impact of the mangosteen farm income in Tasikmalaya is higher than in Subang, the difference of income is statistically significant for both area. Therefore, mangosteen farm income has a major contribution on the family income, especially in Tasikmalaya.

Keywords: mangosteen, farm income, plant maintenance.

\section{PENDAHULUAN}

Komoditas hortikultura menyumbang sekitar $21 \%$ dari PDB sektor pertanian dan menduduki urutan kedua setelah subsektor tanaman pangan, sumbangan terbesar berasal dari buah-buahan sebesar 48.217 miliar rupiah (Ditjen Hortikultura, 2013). Salah satu komoditas hortikultura yang mempunyai prospek cerah untuk tujuan ekspor maupun pasar dalam negeri adalah manggis (Garcinia mangostana, $L$ ). Ekspor manggis menempati urutan pertama ekspor buah Indonesia yaitu sekitar 9,64\% dari total ekspor 26 jenis buahbuahan.

Sentra penamanan manggis di Indonesia adalah di Kaltim, Kalteng, Jawa Barat, Jawa Timur, Sumatra Utara, Sumatera Barat, Riau, dan Sulawesi Utara. Sentra produksi manggis terbesar berada di Jawa Barat yang memberikan kontribusi 20.738 ton atau 
$(18,6 \%)$ terhadap produksi nasional (BPS, 2014). Produksi manggis di Jawa Barat cenderung menurun dalam kurun waktu 20192014 (Tabel 1).

Sentra produksi manggis manggis di Jawa Barat adalah Kabupaten Tasikmalaya, Subang, Ciamis, Bogor, dan Sukabumi (Tabel 1.). Kontribusi produksi manggis dari lima kabupaten tersebut sebesar $96 \%$ terhadap total produksi Jawa Barat. Sentra produksi tersebut merupakan pemasok utama bagi pasar modern (Jakarta dan Bandung) dan pasar ekspor (China, Taiwan, Hongkong, Singapore, dan Timur Tengah).

Tabel 1. Sentra Produksi Manggis di Jawa Barat

\begin{tabular}{llllll}
\hline Kab. & \multicolumn{5}{c}{ Jumlah Produksi (ton) } \\
\cline { 2 - 6 } & 2010 & 2011 & 2012 & 2013 & 2014 \\
\hline Tasik & 13.487 & 12129 & 41294 & 12792 & 10473 \\
Bogor & 376 & 3518 & 22030 & 3282 & 2300 \\
Subang & 3458 & 10360 & 2936 & 3740 & 1253 \\
Skbm & 1707 & 3701 & 2233 & 2595 & 8318 \\
Pwkt & 3210 & 1398 & 3007 & 790 & 1688 \\
Ciamis & 1009 & 1964 & 2002 & 3583 & 857 \\
\hline Jw Barat & 27.983 & 36.861 & 79.444 & 29.753 & 20.738 \\
\hline Sumber: BPS, 2014
\end{tabular}

Meskipun manggis sudah dapat diekspor, namun belum didukung oleh ketersediaan buah dengan mutu yang tinggi. Relatif rendahnya mutu buah manggis di sentra produksi, dikarenakan pengelolaan kebun bersifat tradisional dan system produksinya masih bergantung pada alam. Pada umumnya tanaman manggis sudah tua berumur lebih dari 100 tahun dan warisan orang tua. Peremajaan tanaman baru dilakukan akhir 1990-an (Ditjen Hortikultura, 2013). Kondisi demikian terjadi di sentra produksi manggis seperti di kabupaten Tasikmalaya yang merupakan sentra utama dan di kabupaten Subang yang merupakan sentra ke dua di Jawa Barat.

Masing-masing sentra produksi manggis di Jawa Barat memiliki karakteristik usahatani manggis (pemeliharaan tanaman: penyiangan, pemupukan dan pemberantasan hama penyakit) dan sistem pemasaran yang berbeda. Perbedadaan dalam sistem usahatani dan pemasaran tersebut berpengaruh pada tingkat produksi dan keuntungan petani. Oleh karena itu yang menjadi permasalahan dalam penelitian ini adalah: (1) Bagaimanakah pemeliharaan tanaman di sentra produksi Jawa Barat? (2) Bagaimana perbedaan pendapatan usahatani manggis di sentra produksi Jawa
Barat? (3) Bagaimana kontribusi pendapatan usahatani manggis terhadap pendapatan keluarga petani?

\section{KERANGKA TEORITIS}

Biaya, Penerimaan, dan Pendapatan. Menurut Sukirno (1994), biaya adalah nilai dari semua korbanan ekonomi yang dapat diperkirakan dan yang dapat diukur untuk menghasilkan sesuatu produk. Secara singkat dapat dikatakan bahwa biaya adalah semua nilai faktor produksi yang dipergunakan untuk menghasilkan suatu produk dalam satu periode produksi tertentu.

Biaya usahatani dapat dibedakan atas dua macam yaitu biaya tetap (fixed cost) dan biaya tidak tetap (variable cost). Jumlah biaya tetap ditambah biaya variabel disebut biaya produksi total. Faktor-faktor yang mempengaruhi besar kecilnya biaya usahatani adalah (1) Keadaan fisik dan luas usahatani, (2) Jenis tanaman yang diusahakan, (3) Jenis teknologi yang di terapkan, (4) Waktu melaksanakan usahatani, (5) Tingkat intensitas pengelolaan usahatani, dan (6) Perubahan harga input dan upah tenaga kerja usahatani, serta waktu pembelian input.

Penerimaan usahatani adalah nilai semua produk yang dihasilkan dari suatu usahatani dalam satu periode tertentu satu musim panen atau dalam satuan tahun kegiatan usaha. Penerimaan usahatani merupakan perkalian antara hasil produksi dengan harga jual. Pendapatan usahatani merupakan selisih antara penerimaan dengan total biaya produksi. Pendapatan keluarga petani adalah penjumlahan seluruh pendapatan yang dipeoleh petani pendapatan usahatani dan luar usahatani yang diperoleh selama periode tertentu.

Penelitian Terdahulu. Nugaraha, F. Y (2015) meneliti keuntungan dan resiko usahatani manggis di kecamatan Sagalaherang Subang. Hasil penelitian menunjukkan penerimaan usahatani amggis yang menerapkan SOP adalah Rp.245.125,- per pohon dan penerimaan usahatani manggis petani yang tidak menerapkan SOP adalah Rp.109.412,- per pohon, biaya total petani manggis yang menerapkan SOP adalah Rp.52.702,- per pohon, sedangkan biaya total petani yang tidak menerapkan SOP adalah Rp.22.611,-- per pohon. Keuntungan petani yang menerapkan SOP adalah Rp.192.423,per pohon, sedangkan keuntungan petani yang 
tidak menerapkan SOP adalah Rp.86.802,- per pohon. Resiko usahatani petani manggis yang tidak menerapkan SOP lebih tinggi dari Resiko usahatani petani manggis yang menerapkan SOP, karena kebun petani yang tiak menerapkan SOP kurang terawat

Ramadini, P H (2011) meneliti efek dari penerapan SOP terhadap pendapatan petani di kecamatan Puspahiang Tasikmalaya. Penerimaan petani yang menerpkan SOP adalah Rp.141.787,-- per pohon, sedangkan penerimaan petani yang tidak menerapkan SOP adalah Rp.60.880,- per pohon. Biaya produksi petani yang menerpkan SOP adalah Rp.29.305 per pohon, sedangkan biaya produksi petani yang tidak menerapkan SOP adalah Rp.13.353,- per pohon. Pendapatan petani yang menerpkan SOP adalah Rp.112.482,-- per pohon, sedangkan pendapatan petani yang tidak menerapkan SOP adalah Rp.67.927,-- per pohon. Penerapan SOP tidak mempengaruhi pendapatan petani.

\section{METODOLOGI PENELITIAN}

Desain dan Teknik Penelitian.

Penelitian ini merupakan penelitian kuantitatif dengan teknik penelitian survei deskriptif. Menurut Sugiono (2010), penelitian survei adalah penelitian yang dilakukan pada populasi besar ataupun kecil, tetapi data yang dipelajari adalah data dari sampel yang diambil dari populasi tersebut, sehingga ditemukan kejadian-kejadian relatif, distribusi, dan hubungan-hubungan antar variabel sosiologis maupun psikologis. Metode survei sangat bergantung dari pemilihan responden, pemilihan alat mengumpulkan data, prosedurprosedur yang dilaksanakan, dan kondisi dilapangan.

Jenis dan Sumber Data. Jenis data yang digunakan dalam penelitian ini adalah data primer dan data sekunder. Data primer merupakan data yang di peroleh dari responden dari hasil wawancara langsung. Data sekunder merupakan data pelengkap dari data primer. Data sekunder adalah di peroleh dari studi literature kepustakaan, dokumen instansi seperti Kantor Desa/kecamatan, Perpustakaan, Badan Pusat Statistik, Dinas Pertanian, jurnal dan media internet yang terhubung dengan Penelitian.

Sumber data yaitu responden petani dan informan. Penentuan responden petani menggunakan tekhnik random sampling, sedangkan informan adalah ketua kelompok tani, ketua gapoktan, penyuluh lapangan, kepala pemerintahan setempat, bandar. Teknik pengumpulan data yang digunakan ialah: Observasi (pengamatan), wawancara (interview), dokumentasi dan studi pustaka.

Teknik Penarikan Sampel. Penentuan responden petani menggunakan metoda simpel random sampling, dengan pertimbangan jumlah anggota populasi cukup besar, semakin besar jumlah sampel yang diambil semakin mendekati keadaan sebenarnya. Menurut Gasperzs (1991) apabila peneliti tidak mengetahui ragam dari populasi (S) atau proporsi (P) atau tidak dapat memperkirakannya, maka ukuran sampel (n) dapat diambil 5 persen, 10 persen dan 25 persen. Selanjutnya Gasperzs (1991), untuk ukuran contoh yang lebih besar dari 30 sampel maka sebaran data dalam contoh akan menyebar mendekati sebaran normal. Selain pertimbangan di atas, besaran sampel yang akan diambil di dasarkan pada ketersedian dana dan tenaga yang dimiliki. Dengan pertimbangan di atas, sampel petani manggis diambil sebanyak 5 persen di masing- masing sentra produksi, sehingga diperoleh sampel sebanyak 59 petani manggis di kecamatan Puspahiang Tasikmalaya dan 44 petani Manggis di kecamatan Sagalaherang Subang. Desa sampel di kecamatan Puspahiyang Tasikmalaya adalah desa Puspahiang dan desa Puspajaya, sedangkan desa sampel di kecamatan Sagalaherang adalah desa Sukamandi dan desa Dayeuhkilot, mengingat desa tersebut merupakan desa sentra produksi manggis di masing-masing kecamatan/ kabupaten.

\section{Operasionalisasi Variabel}

Jumlah produksi adalah seluruh produksi manggis petani dalam satu musim panen. Jumlah produksi dinyatakan dalam kg.

Harga Jual adalah sejumlah uang yang diterima petani dari penjualan manggis dinyatakan dalam rupiah per kilogram.

Biaya tetap adalah biaya yang besar kecilnya tidak dipengaruhi oleh perubahan jumlah produksi. Biaya tetap meliputi biaya pajak dan penyusutan alat. biaya tetap ada yang tunai dan non tunai. Dinyatakan dalam satuan rupiah.

Biaya variabel adalah yang besar kecilnya mempunyai pengaruh langsung pada hasil produksi manggis. Biaya variabel terbagi manjadi dua yaitu biaya variabel tunai dan biaya variabel (tunai dan non tunai). Biaya variable dinyatakan dalam rupiah.

Biaya total adalah jumlah biaya tetap ditambah biaya variabel. Biaya total terbagi 
manjadi dua yaitu biaya total tunai dan biaya total (tunai dan non tunai). Biaya total dinyatakan dalam rupiah.

Penerimaan adalah semua produk yang dihasilkan satu musim panen, yaitu merupakan perkalian hasil produksi manggis dengan harga jual per kilogram. Dinyatakan dalam rupiah.

Pendapatan Usahatani adalah pengurangan penerimaan dengan biaya total tunai. Dinyatakan dalam rupiah.

Keuntungan petani manggis (pendapatan bersih) adalah pengurangan penerimaan dengan biaya total (baik tunai maupun non tunai). Dinyatakan dalam rupiah.

Pendapatan keluarga adalah penjumlahan seluruh pendapatan yang dipeoleh petani, meliputi pendapatan usahatani dan luar usahatani yang diperoleh dalam setahun. Pendapatan keluarga dinyatakan dalam rupiah.

Sistem pemasaran manggis adalah cara petani menjual manggis yang meliputi sistem di kilo dan sistem tebasan.

Pemeliharaan tanaman manggis meliputi pemupukan, penyiangan, pemberantasan hama penyakit.

\section{Rancangan Analisis Data} Analisis deskriptif

Analisis deskriptif digunakan untuk menganalisis identifikasi masalah pertama. Analisis deskriptif digunakan untuk menganalisis pemeliharaan (penyiangan, pemupukan, pemberantasan hama penyakit) pemanenan dan sistem pemasaran manggis (sistem dikilo dan sistem ditebas) oleh petani di sentra produksi Jawa Barat.

\section{Analisis Usahatani}

Analisis matematik digunakan untuk menganalisis identifikasi masalah kedua dan ketiga, anallisis matematik yang digunakan adalah analisis usahatani. Dari analisis tersebut akan dihitung biaya penerimaan, pendapatan petani dan keuntungan.

Analisis biaya meliputi biaya variabel, biaya tetap dan biaya total usahatani manggis. Biaya meliputi biaya tunai dan biaya non tunai (Sadono Sukirno, 1994). Biaya tetap ditambah biaya variabel disebut biaya total, atau secara singkat dapat di rumuskan sebagai berikut:

Dimana:

$$
\mathrm{BP}=\mathrm{BT}+\mathrm{BV}
$$

$\mathrm{BP}=$ Biaya total produksi (Rupiah)

$\mathrm{BT}=$ Biaya tetap (Rupiah)

$\mathrm{BV}=$ Biaya variabel (Rupiah)
Penerimaan adalah nilai penjualan manggis yang dihasilkan satu musim panen, yaitu merupakan perkalian hasil produksi manggis dengan harga jual per kilogram, rumus penerimaan manggis adalah:

$$
\mathrm{TR}=\mathrm{Y} \text {. Hy }
$$

Dimana:

$\mathrm{TR}=$ Penerimaan $(\mathrm{Rp})$

$\mathrm{Y}=$ jumlah produksi manggis $(\mathrm{kg})$

Hy $=$ Harga jual manggis $(\mathrm{Rp} / \mathrm{kg})$

Pendapatan Usahatani adalah

pengurangan penerimaan dengan biaya total tunai dengan rumus:

Dimana:

$$
\mathrm{Pdp}=\mathrm{TR}-\mathrm{BP}
$$

$\mathrm{TR}=$ Penerimaan $(\mathrm{Rp})$

$\mathrm{BP}=$ Biaya produksi total (tunai) $(\mathrm{Rp})$

Pdp $=$ Pendapatan petani (Rp)

Keuntungan petani manggis (pendapatan bersih) adalah pengurangan penerimaan dengan biaya total (baik tunai maupun non tunai), rumus keuntungan adalah:

$$
\mathrm{Pd}=\mathrm{TR}-\mathrm{BP}
$$

Dimana:

$$
\begin{aligned}
\mathrm{TR}= & \text { Penerimaan }(\mathrm{Rp}) \\
\mathrm{BP}= & \text { Biaya prod total (tunai, non tunai) } \\
\mathrm{Pd}= & \text { Pendapatan petani }(\mathrm{Rp}) \\
& \text { Pendapatan keluarga petani manggis }
\end{aligned}
$$

adalah penjumlahan seluruh pendapatan yang

diperoleh petani, meliputi pendapatan

usahatani dan luar usahatani yang diperoleh

dalam setahun. Pendapatan keluarga

dinyatakan dalam rupiah.

Kontribusi pendapatan usahatani

amanggis adalah perbandingan antara

pendapatan petani manggis dengan pendapatan keluarga dikali 100 persen.

Analisis statistik

Analisis statistik digunaka untuk menganalisis identifikasi masalah kedua yaitu perbedaan pendapatan petani di sentra produksi manggis Jawa Barat. Uji statistik yang digunakan adalah uji beda (t-student) tidak berpasangan dengan terlebih dahulu melakukan analisis varian. Analisis varians dengan rumus:

$$
F h=\frac{S x^{2}}{S y^{2}}
$$

Apabila diperoleh nilai $\mathrm{F}_{\text {hitung }}>\mathrm{F}_{\text {tabel }}$ maka disimpulkan varians homogen. Pengujian varians homogen dengan rumus:

$$
S p^{2}=\frac{\left(n_{x}-1\right) S x^{2}+\left(n_{y}-1\right) S y^{2}}{n_{x}+n_{y}-2}
$$

Perhitungan nilai $t_{\text {hitung }}$ dengan rumus: 


$$
t_{h}=\frac{(x-y)}{S p \sqrt{\frac{1}{n_{x}}+\frac{1}{n_{y}}}}
$$

Dimana

$$
\begin{aligned}
\mathrm{x}= & \text { rata-rata untung/phn di kab. } \\
& \text { Tasikmalaya }(\mathrm{kg} / \mathrm{phn}) \\
\mathrm{y}= & \text { rata-rata untung/phn di kab. Subang } \\
& (\mathrm{kg} / \mathrm{phn}) \\
\mathrm{S}_{\mathrm{x}}{ }^{2}= & \text { Varians untung/phn di kab. } \\
& \text { Tasikmalaya } \\
\mathrm{S}_{\mathrm{y}}{ }^{2}= & \text { Varians untung/phn di kab. Subang } \\
\mathrm{S}_{\mathrm{p}}{ }^{2}= & \text { Varians untung/phn di kab. Tasik dan } \\
& \text { Subang } \\
\mathrm{n}_{\mathrm{x}}= & \text { Jml sampel petani mgss di kab. } \\
& \text { Tasikmalaya (org) } \\
\mathrm{n}_{\mathrm{y}}= & \begin{array}{l}
\text { Jml sampel petani mgs di kab. Subang } \\
\text { (org) }
\end{array}
\end{aligned}
$$

Dari perhitungan di atas, kaidah keputusannya, apabila $\mathrm{t}_{\text {hitung }}>\mathrm{t}_{\text {tabel }}$ maka dinyatakan terdapat perbedaan hasil produksi manggis di kabupaten Tasikmalaya dan kabupaten Subang, dan sebaliknya, pada tarap nyata 5 persen.

\section{HASIL DAN PEMBAHASAN}

Keadaan Usahatani Manggis. Keadaan usahatani manggis meliputi jumlah pohon manggis yang dimiliki, jumlah pohon yang berbuah, umur pohon manggis, luas lahan (kebun manggis, kebun non manggis dan lahan sawah) dan pemeliharaan kebun manggis.

Keadaan usahatani manggis di kabupaten Subang: jumlah pohon manggis responden berkisar dari 5-225 pohon dengan rata-rata berjumlah 60 pohon. Rata-rata jumlah pohon yang berbuah 32,0 pohon (62 pesen). Keadaan usahatani manggis di kabupaten Tasikmalaya, Jumlah pohon manggis responden berkisar dari 8-240 pohon dengan rata-rata berjumlah 59 pohon. Ratarata jumlah pohon yang berbuah 34,3 pohon (58 persen).

Di kabupaten Subang, rata-rata luas lahan yang dimiliki petani sekitar 0,99 hektar, dimana sekitar 0,41 hektar merupakan kebun manggis (kebun campuran). Rata-rata luas lahan sawah petani manggis 0,74 ha, namun hanya $64 \%$ petani manggis yang memiliki lahan sawah. Di kabupaten Tasikmalaya, ratarata luas lahan yang dimiliki petani sekitar 0,63 hektar, dimana sekitar 0,50 hektar merupakan kebun manggis. Lingkar tajuk pohon manggis berkisar $(6 \times 6) \mathrm{m}$, sementara aturan penanaman pohon manggis berjarak (10 $x$ 10) $\mathrm{m}$. Rata-rata luas lahan sawah petani manggis 0,14 ha, namun hanya $74 \%$ petani manggis yang memiliki sawah.

Pemeliharaan dan Pemasaran. Pohon manggis merupakan tanaman tahunan, petani jarang melakukan peremajaan (pemangkasan). Pohon manggis berbuah setahun sekali, panen manggis antara bulan Desember sampai Maret. Hasil produksi manggis dipengaruhi oleh pemeliharaan kebun, sedangkan pendapatan petani manggis ditentukan oleh hasil produksi dan harga jual. Harga jual yang diterima petani dipengaruhi oleh sistem pemasaran yang diikuti petani.

Pemeliharaan kebun dapat tercermin dari biaya yang dikeluarkan. Besarnya biaya yang digunakan petani manggis di kabupaten Tasikmalaya adalah Rp.74.070,- per pohon, sementara besarnya biaya yang digunakan petani manggis di kabupaten Subang adalah Rp.25.519,- per pohon (Tabel 4), petani mengeluarkan biaya tersebut selama setahun kebelakang (untuk pemupukan, penyiangan) dan pemanenan.

Di Kabupaten Tasikmalaya, jumlah biaya yang digunakan untuk pemupukan adalah Rp.458.501,- per petani per tahun atau Rp.13.759,- per pohon (tabel 2), dana pemupukan digunakan pada bulan Mei, pemupukan tersebut dilakukan sekali setahun (dilakukan oleh $76 \%$ responden), sisanya $13 \%$ memupuk 2 kali setahuan dan $1 \%$ petani tidak melakukan pemupukan.

Di Kabupaten Subang, jumlah dana yang digunakan untuk pemupukan adalah Rp.62.597,- per petani per tahun atau Rp.9.867,- per pohon (tabel 2), dana pemupukan digunakan pada bulan Mei, pemupukan tersebut dilakukan sekali (dilakukan oleh $50 \%$ responden) dalam setahun hanya sebagian kecil (3\% responden) yang memupuk dua kali dalam setahun, sisanya $47 \%$ petani tidak memupuk pohon manggisnya.

Dari uraian di atas terlihat, petani di kabupaten Tasikmalaya lebih banyak memberikan pupuk ke pohon manggisnya dibanding petani manggis di kabupaten Subang, meskipun demikian pemupukan di dua kabupaten tersebut relatif masih sedikit (dibawah standar). Minimnya penggunaan dana untuk pemupukan dikarenakan minimnya dana yang dimiliki petani. Pupuk yang digunakan umumnya pupuk kandang yang 
harganya relatif lebih murah. Pupuk diberikan sekarung per pohon manggis berbuah (satu karung sekitar 30-40 kg dengan harga Rp.10.000,- per karung). Pohon manggis yang belum berbuah umumnya tidak diberi pupuk. Petani memupuk pohon manggis yang akan berbuah (sudah terlihat bunga) dengan harapan buahnya banyak. Minimnya pemupukanyang dilakukan petani menyebabkan buah manggis yang dihasilkan relatif sedikit dan ukurannya kecil.

Tabel 2. Biaya Bahan Usahatani Manggis

\begin{tabular}{lllll}
\hline \multirow{3}{*}{ Bahan } & \multicolumn{2}{l}{ Kab Tasikmalaya } & \multicolumn{2}{l}{ Kab. Subang } \\
\cline { 2 - 5 } & $\begin{array}{l}\text { Nilai/ } \\
\text { petani (Rp) }\end{array}$ & $\begin{array}{l}\text { Nilai/phn } \\
(\mathrm{Rp})\end{array}$ & $\begin{array}{l}\text { Nilai } \\
\text { /petani } \\
(\mathrm{Rp})\end{array}$ & $\begin{array}{l}\text { Nilai/ } \\
\text { phn } \\
(\mathrm{Rp})\end{array}$ \\
\hline Pupuk & $458.501,0(89)$ & $13.758,9$ & 62.597 & 9.867 \\
Pestisida & $149.500,0(0,05)$ & 842,9 & 17.276 & 869 \\
\hline
\end{tabular}

Selain bahan yang digunakan dalam kegiatan usahtani, pemeliharaan memegang peranan penting dalam proses produksi. Pemelihaaan kebun terlihat dari curahan tenaga kerja yang digunakan dalam usahatani manggis meliputi dana untuk penyiangan, pemupukan, pemberantasan hama-penyakit, pemangkasan pohon di sekitar pohon manggis.

Di kabupaten Tasikmalaya, dana untuk penyiaangan digunakan sebesar Rp.489.398,per petani per tahun atau Rp.14.289,- per pohon, penyiangan dilakukan dua kali dalam setahun (78\%), satu kali setahun (15\%), sisanya $7 \%$ memupuk lebih dari dua kali setahun. Sementara di kabupaten Subang, dana untuk penyiangan digunakan sebesar Rp.201.212,- per petani per tahun atau Rp.12.893,- per pohon, penyiangan dilakukan dua kali dalam setahun (dilakukan oleh $61 \%$ responden). Sisanya sekali setahun atau lebih. Minimya kegiatan penyiangan yang dilakukan petani karena kebiasaan mereka kebun manggis dibiarkan, merupakan kebun campuran, dana yang dimiliki. Dampak minimnya dana penyiangan maka kebun petani dipenuhi ilalang, kelihatan kurang terawat. Mereka melakukan penyiangan menjelang pohon manggis berbuah dimaksudkan agar memudahkan saat panen nanti. Petani membiarkan kebunnya karena selain usahatani merupakan usaha sampingan, mereka juga terbatas dana untuk penyiangan.

Di kabupaten Tasikmalaya, dana untuk tenaga kerja memupuk (pekerjaan memberi pupuk) digunakan sebesar Rp.277.727,- per petani per tahun atau Rp.7.281,- per pohon, pemupukan dilakukan satu kali dalam setahun (dilakukan oleh $71 \%$ petani). Sementara di kabupaten Subang, dana untuk tenaga kerja memupuk digunakan sebesar Rp.289.166,- per petani per tahun atau Rp.7.711,- per pohon (dilakukan oleh $36 \%$ petani). Minimnya biaya untuk tenaga kerja memupuk dan sedikitnya jumlah pupuk yang digunakan sangat berpengaruh pada hasil produksi manggis petani.

Biaya untuk tenaga kerja pemangkasan dan pemberantasan hama penyakit relatif kecil baik di kabupaten Tasikmalaya maupun kabupaten Subang, kareana pohon manggis hampir tidak pernah dipangkas demikian juga pemberantasan hama penyakit.

Biaya terbesar digunakan untuk biaya panen dan pengangkutan, di kabupaten Tasikmalaya biaya panen dan pengangkutan per petani adalah Rp.2.807.546,- atau Rp.80.668,- per pohon dan dilakukan oleh $81 \%$ petani (petani yang menjual sistem di kilo), sementara di kabupaten Subang sebesar Rp.626.700,- per petani atau Rp.20.958,- per pohon dan dilakukan oleh $30 \%$ petani.

Biaya panen dengan mengikut penjualan dikilo biasanya dikeluarkan jika petani menggunkan orang lain untuk panen, besarnya biaya tersebut mengikuti sistem borongan yaitu Rp.750,- per kilogram manggis yang dipanen dan Rp.750,-rupiah per kilogram manggis yang di angkut. Biaya panen di kabupaten Tasikmalaya lebih kurang 20\% dari harga jual yang diterima petani (Rp.7.393,- per kilogram). Biaya panen di kabupaten Subang lebih kurang $30 \%$ dari harga jual yang diterima petani (harga manggis Rp.5.304,- per kilogram). Sistem panen borongan ini berpengaruh pada kualitas manggis yang dihasilkan karena pemborong pemetik mengejar jumlah petikan ataupun pengangkutan, hal ini berpengaruh pada kualitas manggis yang dipetik, mengingat kualitas manggis salah satunya ditentukan oleh sistem pemanenan. Banyaknya buah manggis yang memar akan menurunkan harga jual. Rincian selengkapnya dapat dilihat di tabel di bawah ini.

Dari uraian di atas terlihat, petani di kabupaten Tasikmalaya lebih lebih memelihara kebun manggisnya dibanding petani manggis di kabupaten Subang, hal tersebut terlihat lebih banyaknya petani yang melakukan pemangkasan sekitar pohon manggis, pemupukan, penyiangan dan pemeliharaan lainnya. 
Tabel 3. Biaya Tenaga Kerja Usahatani Manggis

\begin{tabular}{lcccc}
\hline \multirow{2}{*}{ Kegiatan } & \multicolumn{2}{c}{ Kab.Tasikmalaya } & \multicolumn{2}{c}{ Kab. Subang } \\
\cline { 2 - 5 } & $\begin{array}{c}\text { Nilai per petani } \\
(\mathrm{Rp})\end{array}$ & Nilai / phn & Nilai (Rp) & Nilai /phn \\
\hline Penyiangan & $489.398(99)$ & $14.289,0$ & $201.212(61)$ & 12.893 \\
Pangkasan & $95.200(31)$ & $2.846,4$ & $0(0)$ & 0 \\
Pemupukan & $277.727(71)$ & $7.280,7$ & $289.166(36)$ & 7.711 \\
Pemberantasan HPT & $0,0(0)$ & 0 & $125.000(12)$ & 1.785 \\
Pemanenan & $1.403 .773(81)$ & $40.334,7$ & $313.350(30)$ & 10.479 \\
Angkutan & $1.403 .773(81)$ & $40.334,7$ & $313.350(30)$ & 10.479 \\
\hline
\end{tabular}

Keterangan: ( ) Persentase petani yang melakukan

Selain biaya variabel, biaya selanjutnya adalah biaya tetap yang meliputi biaya alat dan pajak lahan (PBB). Alat yang digunakan untuk penyiangan diantaranya cangkul, kored, arit, dll. Penyiangan dilakukan secara manual untuk pembabatan gulma. Alat untuk panen dilakukan dengan menggunakan galah, dan untuk penyimpanan buah manggis digunakan keranjang yang biasanya disediakan para bandar.

Di kabupaten Tasikmalaya, biaya tetap (termasuk peralatan dan PBB) yang dikeluarkan petani setahun sebesar Rp.191.262,- per tahun atau Rp.5.576,-- per pohon, sementara di kabupaten Subang, biaya tetap yang dikeluarkan petani setahun sebesar Rp.223.257,- atau Rp.6.979,-- per pohon.

Tabel 4. Biaya Tetap Usahatani Manggis

\begin{tabular}{lllll}
\hline Biaya & \multicolumn{2}{l}{ Kab. Tasikmalaya } & \multicolumn{2}{l}{ Kab. Subang } \\
\cline { 2 - 5 } & $\begin{array}{l}\text { Nilai/ } \\
\text { petani }\end{array}$ & $\begin{array}{l}\text { Nilai/ } \\
\text { phn }\end{array}$ & $\begin{array}{l}\text { Nilai/ } \\
\text { petani }\end{array}$ & $\begin{array}{l}\text { Nilai/ } \\
\text { phn }\end{array}$ \\
\hline alat & $85.425,0$ & $2.490,5$ & 130.000 & $4.062,5$ \\
PBB & $105.837,5$ & $3.085,6$ & 93.257 & $2.914,2$ \\
B.tetap & $171.143,8$ & $4.991,6$ & 223.257 & $6.976,7$ \\
\hline
\end{tabular}

Tabel 5. Biaya Usahatani Manggis

\begin{tabular}{lllll}
\hline \multirow{2}{*}{ Biaya } & \multicolumn{2}{l}{ Kab. Tasikmalaya } & \multicolumn{2}{l}{ Kab.Subang } \\
\cline { 2 - 5 } & $\begin{array}{l}\text { Nilai per } \\
\text { petani (Rp) }\end{array}$ & $\begin{array}{l}\text { Nilai } \\
\text { /pohon } \\
(\mathrm{Rp})\end{array}$ & $\begin{array}{l}\text { Nilai } \\
\text { /petani } \\
(\mathrm{Rp})\end{array}$ & $\begin{array}{l}\text { Nilai } \\
\text { /pohon } \\
(\mathrm{Rp})\end{array}$ \\
\hline variabel & $2.368 .520,0$ & $69.078,2$ & 593.366 .7 & $18.542,7$ \\
tetap & $171.143,8$ & $4.991,6$ & $223.257,0$ & $6.976,7$ \\
Tot biaya & $2.539 .664,0$ & $74.069,7$ & $816.624,0$ & $25.519,5$ \\
\hline
\end{tabular}

Penjumlahan biaya variabel dan biaya tetap merupakan biaya total usahatani. Biaya total usahatani di kabupaten Tasikmalaya adalah Rp.2.539.664,- per petani atau Rp.74.070,- per pohon, sedangkan biaya total usahatani di kabupaten Subang adalah Rp.816.624,- per petani atau Rp.25.519,-- per pohon (seperti yang terlihat di Tabel 5), dengan demikian petani manggis di
Tasikmalaya membiayai pohon manggisnya tiga kali lebih banyak dibanding petani manggis di Subang.

Penerimaan dan Sistem Penjualan. Di kabupaten Tasikmalaya, penerimaan dengan sistem tebasan sekitar Rp.271.300,- per pohon, dan penerimaan dengan sistem dikilo Rp.646.243,- per pohon (harga jual per kilo Rp.7.394,-, satu pohon menghasilkan sekitar 88,5 kilogram). Total penerimaan per petani di kabupaten Tasikmalaya Rp.20.066.137,rupiah per tahun atau Rp.585.232,- per pohon,

Tabel 6. Penerimaan Usahatani Manggis

\begin{tabular}{|c|c|c|c|}
\hline Sistem penjualan & Sat & Kab. Tasikmly & Kab. Subang \\
\hline \multicolumn{4}{|l|}{ SIS.TEBASAN } \\
\hline Jumlah petani & persen & 16 & 60 \\
\hline Rata-rata jml pohon & pohon & 31,9 & 39,25 \\
\hline Harga per pohon & $\mathrm{Rp} / \mathrm{phn}$ & $271.300,4$ & $124.203,80$ \\
\hline Penerimaan tebasan & $\mathrm{Rp}$ & $8.642 .857,14$ & $4.874 .999,15$ \\
\hline \multicolumn{4}{|l|}{ Penjualan kilo } \\
\hline Jumlah petani & persen & 84 & 40 \\
\hline Rata-rata per petani & $\mathrm{kg}$ & $3.041,65$ & 489,29 \\
\hline Harga per kilogram & $\mathrm{Rp} / \mathrm{kg}$ & $7.393,8$ & 5.304 \\
\hline Penerimaan dikilo & $\mathrm{Rp}$ & $22.489 .257,58$ & $2.595 .141,12$ \\
\hline \multicolumn{4}{|l|}{ PENERIMAAN } \\
\hline Nilai penerimaan & $\mathrm{Rp}$ & $20.066 .137,50$ & $4.336 .969,70$ \\
\hline Rata-rata jml pohon & Phn & 34,28 & 32 \\
\hline Penerimaan $\mathrm{p} /$ pohon & Rp/phn & $585.231,8$ & $135.658,76$ \\
\hline
\end{tabular}

Di kabupaten subang, lebih banyak petani yang menjual manggisnya dengan sistem tebasan (60\%), sementara petani manggis di kabupaten Tasikmalya hanya 16\% petani yang menjual hasilnya dengan sistem tebasan di kabupaten Subang, penerimaan yang diterima petani dengan sistem tebasan sekitar Rp.124.024,- per pohon, dan penerimaan yang diterima petani dengan sistem dikilo Rp.151.358,- per pohon (harga jual per kilo Rp.5.304,-, satu pohon menghasilkan sekitar 28,5 kilogram). Di kabupaten Subang, nilai total penerimaan per petani Rp.4.336.970,- per tahun atau Rp.135.659,- per pohon. 
Tingginya penerimaan petani manggis di kabupaten Tasikmalaya dibanding penerimaan petani di kabupaten Subang disebabkan oleh beberapa faktor diantaranya: Harga jual yang diterima petani manggis di kabupaten Tasikmalaya lebih tinggi karena selain jumlah produksi per pohon yang lebih banyak juga karena kualitas manggis yang dihasilkan lebih baik. Kulaitas yang lebih baik tersebut karena sistem pemeliharaan kebun yang lebih baik dan sistem panen lebih baik (sistem dikilo dan dipanen sendiri), mengigat kualitas manggis banyak ditentukan oleh sistem panen yang hati-hati. Menurut Ramadini (2011), Petani yang menerapkan SOP menghasilkan buah manggis dengan perbandingan mutu super dan bekas sortir (BS): 60:40\%.

\section{Pendapatan dan Keuntungan.}

Pendapatan usahatani manggis adalah selisih antara penerimaan dengan total biaya. Pendapatan petani manggis di kabupaten Tasikmalaya adalah Rp.17.526.474,- per petani atau Rp.591.592,- per pohon, sementara pendapatan petani manggis di kabupaten Subang adalah Rp.3.650.345,- per petani atau Rp.110.011,- per pohon (Tabel 7), dengan demikian pendapatan petani manggis di kabupaten Tasikmalaya lebih besar dibanding pendapatan petani manggis di kabupaten Subang, hal tersebut dikarenakan selain harga jual yang tingi juga kuntitas produksi manggis di kabupaten Tasikmalaya yang lebih tinggi.

Tabel 7. Biaya, Penerimaan dan Pendapatan Petani

\begin{tabular}{lllll}
\hline \multirow{2}{*}{ Uraian } & \multicolumn{2}{l}{ Kab. Tasikmalaya } & \multicolumn{2}{l}{ Kab.Subang } \\
\cline { 2 - 5 } & $\begin{array}{l}\text { Nilai /petani } \\
(\mathrm{Rp})\end{array}$ & $\begin{array}{l}\text { Nilai } / \mathrm{phn} \\
(\mathrm{Rp})\end{array}$ & $\begin{array}{l}\text { Nilai } \\
\text { /petani } \\
(\mathrm{Rp})\end{array}$ & $\begin{array}{l}\text { Nilai } \\
\text { /phn } \\
(\mathrm{Rp})\end{array}$ \\
\hline Peneriman & 20.066 .137 & 585.231 & 4.336 .969 & 135.658 \\
Total biaya & 2.539 .664 & 74.069 & 816.624 & 25.519 \\
Pendapatan & 17.526 .474 & 591.592 & 3.650 .345 & 110.010 \\
\hline
\end{tabular}

Keuntungan merupakan selisih penerimaan dengan biaya total (tunai dan non tunai). Keuntungan usahatani manggis di kabupaten Tasikmalaya adalah Rp.542.304,- per pohon, sedangkan keuntungan usahatani manggis di kabupaten Subang adalah Rp.83.063,- per pohon, hasil tersebut tidak berbeda jauh dengan hasil penelitian Nugraha (2015), keuntungan petani manggis di kabupaten Subang Rp.192.423,-- per pohon (yang menerapkan SOP), dan Rp.86.802,-- (yang tidak menerapkan SOP), dengan demikian keuntungan usahatani manggis di kabupaten Tasikmalaya lebih besar di banding keuntungan usahatani manggis di kabupaten Subang.

Hasil analisis varians menunjukan varians yang homogen dari keuntungan usahatani manggis di kabupaten Tasikmalaya dan subang ditunjukan oleh nilai $\mathrm{F}_{\text {hitung }}=2,43$ $\left(F_{\text {tabel }}=1,64\right.$. hasil pengujian t-statistik menunjukan perbedaan pendapatan secara signifikan antara keuntungan usahatani manggis di kabupaten Tasikmalaya dan Subang dengan nilai $\mathrm{T}_{\text {hitung }}=3,94\left(\mathrm{t}_{\text {tabel }}=\right.$ $1,65)$.

Kontribusi Pendapatan Manggis. Penjumlahan pendapatan usahatani manggis dengan pendapatan lainnya diluar usahatani manggis di sebut pendapatan keluarga. Di kabupaten Tasikmalaya, pendapatan keluarga petani manggis per tahun sebesar Rp.

25.712.844,- yang terdiri dari berbagai sumber: usahatani non manggis yang meliputi usahatani (sawah, usahatani tegalan) dan diluar usahatani (pensunan, wiraswasta dll). Pendapatan usaha tani manggis ternyata merupakan pendapatan utama mengingat kontribusinya $68,2 \%$ (Rp.17.526.475,-) terhadap pendapatan keluarga, sisanya sebesar $31,8 \%$ berasal dari pendapatan diluar usahatani manggis.

Di kabupaten Subang, pendapatan keluarga petani manggis per tahun sebesar Rp. 26.084.588,- yang terdiri dari berbagai sumber usahatani non manggis yang meliputi usahatani (sawah, usahatani tegalan) dan diluar usahatani (pensiunan, wiraswasta dll). Pendapatan usahatani manggis ternyata hanya merupakan pendapatan sampingan mengingat kontribusinya hanya 13,9\% (Rp.3.650.345,-) terhadap pendapatan keluarga, sisanya sebesar $86,1 \%$ berasal dari pendapatan diluar usahatani manggis.

\section{KESIMPULAN}

Hasil pembahasan menunjukkan bahwa petani manggis di kabupaten Tasikmalaya lebih memelihara kebun manggisnya dibanding petani manggis di kabupaten Subang. Hal ini menunjukkan masih adanya potensi peningkatan kualitas dan produktivitas manggis di kedua kabupaten tersebut. Keuntungan usahatani manggis di kabupaten Tasikmalaya lebih tinggi dibanding keuntungan usahatani manggis di kabupaten Subang. Pendapatan usahatani manggis memiliki peranan/kontribusi yang besar terhadap pendapatan keluarga petani manggis di kabupaten Tasikmalaya dan sebaliknya di kabupaten Subang. 


\section{DAFTAR PUSTAKA}

BPS. (2014). Statistik Tanaman Hortikultura. Badan Pusat Statistik. Jakarta

Dinas Pertanian Kabupaten Tasikmalaya. (2012). Potensi Tanaman Buahbuahan. Melalui: www. tasikmalayakota.go.id (1/6/2015)

Ditjen Hortikultura. (2013). Rencana Strategis Dirjen Hortikultura. Jakarta.

Direktorat Budidaya Tanaman Buah (2009). Standar Operasional Prosedur Kab. tasikmalaya Melalui: www.deptan.go.id (1/6/2015)

Gaspez, Vincent. (1991). Tehnik pengambilan Contoh untuk Penelitian Survei.
Tarsito, Bandung.

Ramadini P H (2011). Pengaruh Penerapan Standar Operasional prosedur terhadap pendapatan Petani Manggis di kecamatan Puspahiang Tasikmalaya. Fakultas Pertanian Unpad. Bandung.

Sugiono. (2010). Metoda Penelitian Kuantitatif, Kualitatif, R\&D. Alfabeta Bandung.

Sukirno. (1994). Mikro Ekonomi. PT Raja Grafindo Persada. Jakarta

Nugraha, F Y. (2015). Keuntungan dan Resiko Usahatani Manggis yang menerapkan SOP dan tidak menerapkan SOP. Fakultas Pertanian Unpad. Bandung. 